\title{
THE CONCEPT FOR A RECLAMATION TECHNOLOGY OF POLLUTED SMALL WATER RESERVOIRS, WITH THE APPLICATION OF MBBR REACTORS
}

\author{
Robert Mazur $\bowtie$ \\ Department of Geoinformation, Photogrammetry and Remote Sensing of Environment, Faculty of Mining, \\ Surveying and Environmental Engineering, AGH University of Science and Technology, 30-059 Krakow
}

\begin{abstract}
Aim of the study

Adaptation of MBBR technology for the treatment of highly degraded waters in small water reservoirs. Investigation of the effectiveness of organic pollutants treatment in waters with highly polluted (or easily biodegradable) municipal sewage. Checking the effectiveness of nutrient removal during the process of cleaning this type of pollutants.
\end{abstract}

\begin{abstract}
Material and methods
The study was conducted in laboratory conditions on a semi-technical scale. Diluted municipal sewage was treated in order to determine purification efficiency for each laboratory stand. The experiments were carried out in 4 research stands (volume of wastewater in each tank amounted to $1000 \mathrm{~L}$ ), whereas each was equipped with a MBBR bioreactor with a moving bed (biofilm carriers). The physicochemical parameters of $\mathrm{pH}$, redox, and oxygen concentration were examined, and laboratory analyses were performed to indicate changes in COD, BOD5, and selected forms of NH4 and PO4. On the basis of the obtained results, the effectiveness of the wastewater treatment was demonstrated, and the hydraulic parameters of the installation were modelled.

\section{Results and conclusions}

The results of experimental work indicate a significant effectiveness of the process of purifying and removing nutrients in MBBR installations. After designing a suitable floating platform, it will be possible to introduce such installations into degraded water reservoirs for their purification.
\end{abstract}

Keywords: MBBR; water treatment; water reservoirs reclamation; water pollution

\section{INTRODUCTION}

There is no unambiguous definition of "small water reservoirs" in the EU Water Framework Directive (WFD, 2000; Jurik et al., 2015). In the literature, many classifications can be found in relation to the reservoirs ranging from $1 \mathrm{~m}^{2}$ to $2-5$ ha (Annor, 2007; Oertli et al., 2009; Boix et al., 2012; Payen et al., 2012; Nascimento and Neto, 2017). With respect to the capacity, various authors adopt different criteria for small water reservoirs, from a few cubic meters to $100000 \mathrm{~m}^{3}$ (Mioduszewski, 2012; 2014), and below 1 million $\mathrm{m}^{3}$ (Liebe et al., 2005; Payen et al., 2012).

Jurik, citing the Slovak Standard STN 736824, classifies reservoirs with a capacity of up to 2 million $\mathrm{m}^{3}$ as small reservoirs (Jurik et al., 2015). Small water reservoirs were excluded from the water bodies of stagnant water in the WFD because their surface is

凶e-mail:mazurrob@gmail.com 
less than $0.5 \mathrm{~km}^{2}$ (Jurik et al., 2015). The above issue means that in their majority, they remain outside the monitoring control in most of the EU Member States (Schwartz and Jenkins, 2000). Only the provision on the protection of agricultural land allows active conservation of the water quality of small water reservoirs located within the area of such land (RDW, 2000).

These reservoirs are characterized by low tolerance to the impact of pollutants, and the effects of their emission are very quickly visible in the form of a decrease in surface water quality and degradation of water ecosystems (Brucet et al., 2013). Due to the legal issues, the process of reclamation of this type of reservoirs is treated marginally and the choice of treatment methods is mainly influenced by economic factors. The application of multi-criteria analyses for the selection of reclamation methods often indicates biological methods as the best solution for water reservoirs (Uberman et al., 2012; Wąsik et al., 2017b). These methods allow for the elimination of pollution through biochemical changes. They do not generate additional compounds from chemical processes. They do not change edaphic conditions; on the other hand, they restore the dynamic balance of the aquatic environment and the reproduction of renewable resources. They also restore species biodiversity, specific to a given ecosystem. They reestablish the proper structure of the trophic network in the degraded water environment. They restore the proper oxygen and light profile in the water environment, and they mitigate the eutrophication process in water reservoirs (Cooke, 2016). The literature describes the use of natural wetlands and constructed wetlands in the process of effective treatment of water reservoirs or wastewater (Mitsch and Gosselink, 2000; Hamilton and Collier, 2016; Brönmark and Hansson, 2017; Larocque-Tobler, 2017). In a significant portion of small water reservoirs, it is impossible to create a marsh zone, and active reclamation methods are recommended instead. Active biological methods for cleaning lakes include a group of technologies based on aeration processes and the use of microorganisms with high affinity to the organic substrate (Sitarek et al., 2017). The amount of pollutant loads is a key criterion affecting the economics of the purification process. Regardless of the selected reclamation method, sources of pollutant emissions should be eliminated or significantly reduced in the first stage. In the case of fish ponds (fish aquaculture), the density of aquatic organisms also affects the intensity of the production of pollutants (Pokorný and Hauser, 2002; Husa et al., 2014). The author carried out research on the use of the moving bed biofilm reactor (MBBR) for the purification of small water reservoirs. Study of literature allowed the author to select MBBR as the technology showing the highest potential for the application in the reclamation of water reservoirs. The main advantages of these bioreactors include:

1. High tolerance to temperature changes and uneven organic loads.

2. Purification efficiency, which is comparable to SBR (sequencing batch reactor) or better.

3. Low production of sewage sludge biomass and high retention of microorganisms in the reactor system. (Andreottola et al., 2000a; Hosseiny and Borghei, 2002; Borkar et al., 2013; Ateia et al., 2016).

Effective use of microflora that is able to purify water reservoirs requires maintaining the control over basic parameters of the environment. Water temperature, which determines biochemical transformation processes, must be above $5^{\circ} \mathrm{C}$. The concentration of oxygen in water should not fall below $2 \mathrm{mg} \cdot \mathrm{dm}^{-3}$ (Sitarek et al., 2017). It is extremely difficult to maintain proper time of hydraulic retention in reactors under the conditions of continuous flow, therefore a quasi-continuous purification system is proposed. The use of the water-air lift technology allows full mixing inside the reactor and the circulation of the bed in the reaction chamber. Such a system minimizes the amount of energy needed for the operation of the entire installation, and it facilitates the ultimate discharge of the purified substrate to the aquatic environment. Based on a detailed analysis of the above parameters, the MBBR reactor was designed to be completely submerged in a water reservoir. The reactor bed was made of PE fittings with $\varphi=16 \mathrm{~mm}$ and length $=25 \mathrm{~mm}$. Both hydraulic testing of the technological model and biotechnological testing of the model in the semi-technical scale were performed. The aim of the laboratory tests was to obtain information on the MBBR's parameters of performance. The obtained results will facilitate adapting the installation to the working conditions in a contaminated water reservoir, and predicting the effectiveness of the treatment process. 
Mazur, R. (2019). The concept for a reclamation technology of polluted small water reservoirs, with the application of MBBR reactors. Acta Sci. Pol., Formatio Circumiectus, 18 (2), 121-133. DOI: http://dx.doi.org/10.15576/ASP.FC/2019.18.2.121

\section{METHODS AND MATERIALS}

\section{A. Hydraulic tests of the reactor on a technical scale}

The author built a prototype bioreactor (see: Fig. 1), and adjusted the bed parameters to the optimal results of hydraulic tests. The reactor during the test was completely submerged in water (see: Fig. 2).

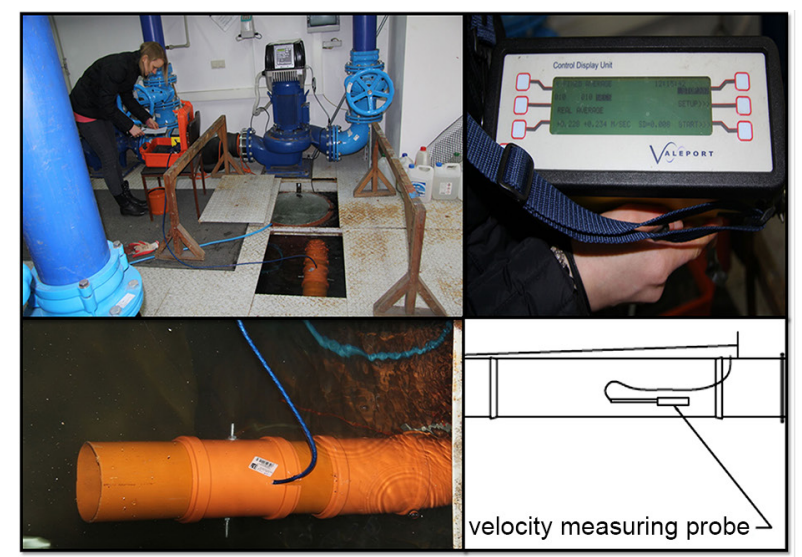

The model of the reactor was designed and built on the geometry of a cylinder tube with the inner diameter of $D=600 \mathrm{~mm}$ and height $H s=1700 \mathrm{~mm}$, made of polypropylene (PP), heavy type SN 8. The direction of medium flow through the reactor (Q1) was forced by the pressure difference created between the aeration chamber and the external environment. The water is sucked through the strainer (filter) and it then flows

Fig. 1. The MBBR reactors A. Diagram of a prototype reactor B. A prototype bioreactor on a technical scale

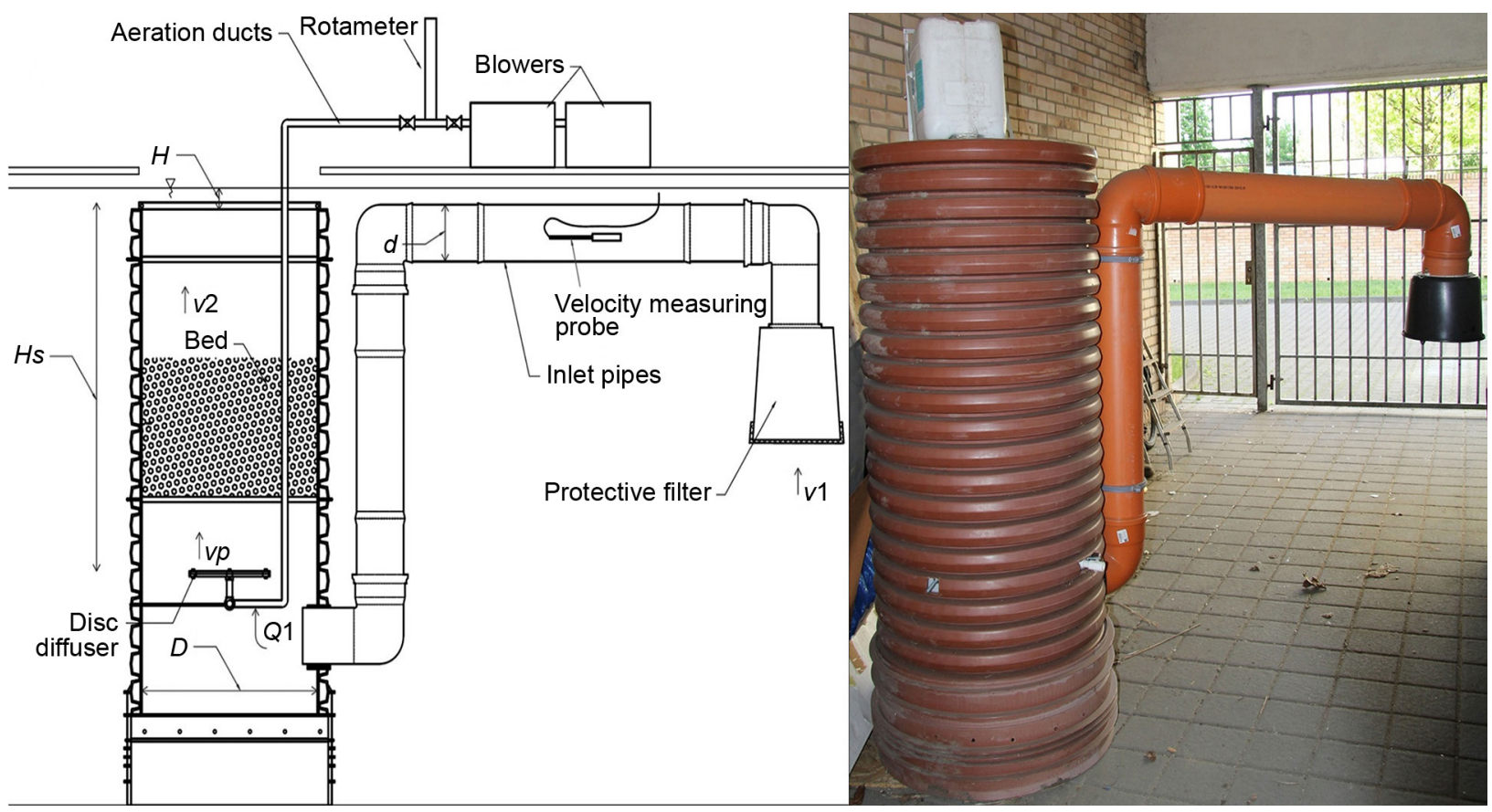

Fig. 2. Experimental stand for hydraulic testing of MBBR bioreactors A. Research infrastructure 
into the aeration zone through the supply pipe with $\varphi=160 \mathrm{~mm}$. A diffuser is mounted above the intake connector, ensuring aeration as well as the creation of a suitable water-air mixture. The deep aeration (fine bubble) system, based on the Akwatech 240 PD-type membrane diffuser with a diameter $\varphi=275 \mathrm{~mm}$ and active area of $260 \mathrm{~cm}^{2}$ (see: Fig. 1) was used in the bioreactor. Water velocity in the inlet pipe $(v 1)$ differs from velocity in the bioreactor $(v 2)$ due to the difference in diameters of the inlet pipe $(\mathrm{d}=160 \mathrm{~mm})$ and the bioreactor $(D=600 \mathrm{~mm})$. The difference between the top edge of the reactor and the water table was $50 \mathrm{~mm}(H)$. Fine bubble diffuser generated aeration, and the velocity of gas $(v p)$ was higher than liquid face

\section{B. Circulation of biomass carriers in cases of $50 \%$ and $70 \%$ chamber filling}

Hydraulic tests stand were carried out in a laboratory pool, with completely submerged reactor (see: Fig. 2):

The water flow rate into the reactor was measured with a Valeport device, model 801. Aeration was ensured using the Hilbow HP - 100 membrane blowers, air flows were determined on the Tecfluid model PSM -2 rotameters. Based on the results of water flow rate, the flow through the reactor and the remaining hydraulic parameters of the reactor chamber were calculated.

\section{Biotechnological testing of the bioreactor in a laboratory model}

Biotechnological tests were conducted on models in a semi-technological scale, $1: 3$ to the prototype model. The three bioreactors were tested in a full flooding system, in a tank of $\mathrm{V}=1 \mathrm{~m}^{3}$. The construction of the installation enabled treated wastewater to fully circulate (see: Fig. 3a, 3b). The bioreactors diameter was $400 \mathrm{~mm}$, and total high was $\mathrm{L}=900 \mathrm{~mm}$, with $\mathrm{L}=700 \mathrm{~mm}$ in the reaction chamber. Inlet pipes diameter was $160 \mathrm{~mm}$, excluding protective filter baskets. These test stands were located in the screening station of communal wastewater treatment plant (see: Fig. A).

The treatment process was carried out on municipal wastewater diluted in a ratio of $1: 2$, characterized by the following parameters: $\mathrm{COD}_{\text {total }}: 170$ $-250 \mathrm{mg} \cdot \mathrm{dm}^{-3} \mathrm{O}_{2}, \mathrm{BOD}_{5}: 80-160 \mathrm{mg} \cdot \mathrm{dm}^{-3} \mathrm{O}_{2}$. The nutrients concentration were respectively: $\mathrm{NH}_{4}^{+}$: $40-45 \mathrm{mg} \cdot \mathrm{dm}^{-3}$ and $\mathrm{PO}_{4}^{3-}: 4-7 \mathrm{mg} \cdot \mathrm{dm}^{-3}$. The aeration was conducted using analogous solutions as in the prototype installation. The airflow was set at the level of $Q_{a}=2.4 \mathrm{~m}^{3} \cdot \mathrm{h}^{-1}$, at which the velocity and flow of the sewage through the bed of the reactor was obtained, respectively: $Q_{s}=7.15 \mathrm{~m}^{3} \cdot \mathrm{h}^{-1}$ and $v=0.33 \mathrm{~m} \cdot \mathrm{s}^{-1}$. Samples for laboratory analysis were collected before the beginning of the treatment process, and again after 24 hours. Online monitoring of $\mathrm{O}_{2}$ concentration and redox was also carried out

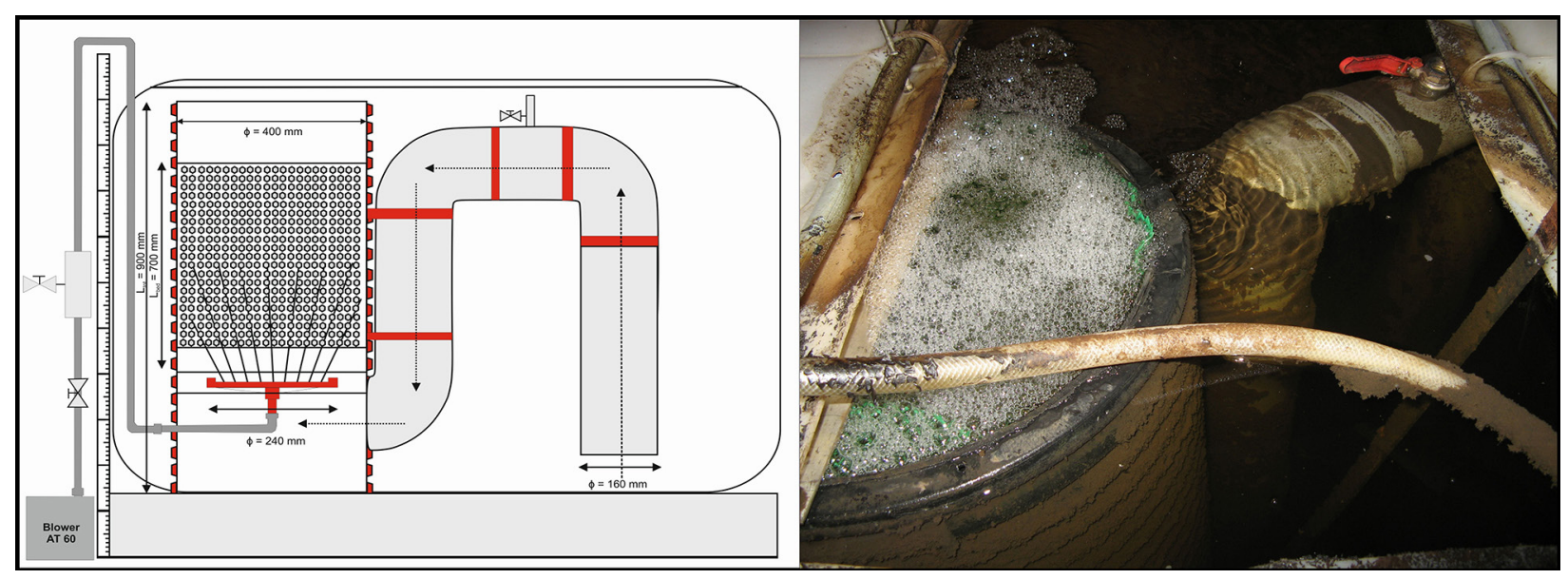

Fig. 3. MBBR reactor on a laboratory scale A. Diagram of an experimental bioreactor installation. B. Experimental installation during wastewater treatment 
Mazur, R. (2019). The concept for a reclamation technology of polluted small water reservoirs, with the application of MBBR reactors. Acta Sci. Pol., Formatio Circumiectus, 18 (2), 121-133. DOI: http://dx.doi.org/10.15576/ASP.FC/2019.18.2.121

in one of the reactors. All reactors operated in the MBBR system in the water-air lift mode. The total area of the biological bed of each reactor was $30.8 \mathrm{~m}^{2}$. The reactor operation was set in the following mode: 30 minutes of nitrification phase (aerobic conditions) and 30 minutes of denitrification phase (anoxic condition - without mixing).

\section{Laboratory analysis and analytical procedures}

Before laboratory analysis, all samples were filtered on Whatman brand filters, characterized by $0.4 \mu \mathrm{m}$ pore size. The laboratory analyses included parameters such as: $\mathrm{COD}, \mathrm{NH}_{4}$ and $\mathrm{PO}_{4}$ in spectrophotometer NOVA 60 Spectroquant ${ }^{\circledR}$.

The following procedures by Merck Millipore were applied: method 114555 - COD cuvette test, for oxygen in range of $500-10000 \mathrm{mg} \cdot \mathrm{dm}^{-3}$, and samples were mineralized in $148^{\circ} \mathrm{C}$ for $120 \mathrm{~min}$ before indication, method PB-06 for the determination of $\mathrm{NH}_{4}^{+}$ions (ammonium test - 100683) and PB07 for determination of $\mathrm{PO}_{4}^{3-}$ (orthophosphate test - 100616). $\mathrm{BOD}_{5}$ was determined according to the Oxi-Top protocol (in dark glass bottles with continuous stirring at $20^{\circ} \mathrm{C}$ ).

\section{RESULTS}

\section{A. The hydraulic test results for the technical model}

Due to the complexity of the process, in order to determine the contact time between the medium and the bed, the Zuber-Findlay mathematical model was used (Natarajan et al., 2008). Using the following relationship, it is possible to determine the proportion of the gas phase in the mixture.

$$
\frac{u_{G}}{\alpha_{G}}=C_{0} \cdot u_{T P}+v_{d r}
$$

where:

$u_{G}$ - gas apparent velocity, $\mathrm{m} \cdot \mathrm{sec}^{-1}, \alpha_{G}-$ gas phase share in the mixture;

$C_{0}-$ distribution coefficient, $v_{d r}-$ drift velocity (speed), $\mathrm{m} \cdot \mathrm{sec}^{-1}$,

$u_{T p}-$ mixture apparent velocity, $\mathrm{m} \cdot \mathrm{sec}^{-1}$.

In order to determine the flow structure, the author applied a universal regime map for the horizontal flow of an air/water mixture with a bubbly structure in Ulbricht' reactor. In order to increase the accuracy of the model, the correlation equation for drift velocity was used, as well as $\mathrm{C}_{0}$ coefficient.

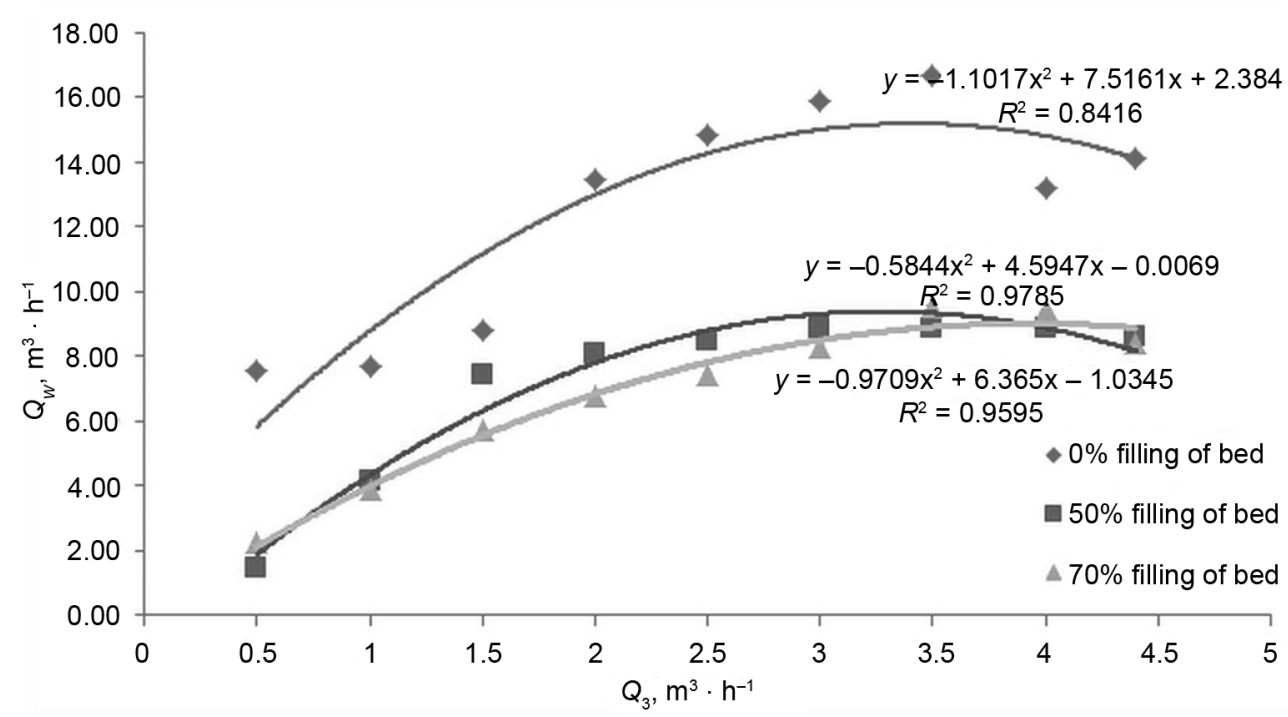

Fig. 4. The flows of the mixture through the bed depending on the air flow, with various fillings of bed by the carriers 
$C_{0}=1.2-0.2 \sqrt{\frac{\rho G}{\rho L}} ; \quad v_{d r}=0.52\left(\frac{g D_{h} \Delta \rho}{\rho L}\right)^{1 / 2}, \quad \mathrm{~m} \cdot \mathrm{s}^{-1}$

where:

$$
\begin{aligned}
\rho L=\rho W- & \text { bulk density of the liquid, } \mathrm{m}^{3} \cdot \mathrm{kg}^{-1} ; \\
& \mathrm{g}-\text { gravitational acceleration, }
\end{aligned}
$$

Based on the literature data, the following values were chosen (Dziubiński \& Prymer 2009):

$$
\rho L=\rho W=1000 \mathrm{~m}^{3} \cdot \mathrm{kg}^{-1}, \rho G=\rho P=\mathbf{1 . 2 9} \mathrm{m}^{3} \cdot \mathrm{kg}^{-1},
$$

The retention time of mixtures in biological bed was calculated as:

$$
t_{p z}=\frac{V_{z} \varepsilon \alpha_{L}}{Q_{1}}, \min
$$

where:

$V_{z}$ - moving bed volume, $\mathrm{m}^{3}$;

$\varepsilon-$ the porosity of carriers;

$\alpha_{L}-$ volume ratio of the liquid phase in the mixture;

$Q_{1}$ - inflow intensity of liquid into the reactor, $\mathrm{m}^{3} \cdot \mathrm{h}^{-1}$,
Table 1. The results $\left(t_{p z}\right)$ of pollutants retention time in the biological bed depending on the degree of bed filling and airflow

\begin{tabular}{ccc}
\hline $\begin{array}{c}\text { Intensity of } \\
\text { supplied air } \\
{\left[\mathrm{m}^{3} \cdot \mathrm{h}^{-1}\right]}\end{array}$ & $\begin{array}{c}\text { Carrier filling ratio } \\
\text { at } 50 \%\end{array}$ & $\begin{array}{c}\text { Carrier filling ratio } \\
\text { at } 70 \%\end{array}$ \\
\hline 1 & 7.37 & 13.09 \\
\hline 1.5 & 4.11 & 8.76 \\
\hline 2 & 3.71 & 7.31 \\
\hline 2.5 & 3.51 & 6.64 \\
\hline 3 & 3.32 & 5.87 \\
\hline 3.5 & 3.29 & 5.06 \\
\hline 4 & 3.25 & 5.04 \\
\hline 4.5 & 3.32 & 5.61 \\
\hline
\end{tabular}

\section{B. Biotechnology research results for a laboratory model}

The hydraulic retention time was (HRT) $0.088 \mathrm{~d}$.

The results of organic reduction in sewage pollution are satisfactory for the wastewater treatment period (during 24h) (see: Fig. 5 and 6).

The reduction rate for both parameters, COD and $\mathrm{BOD}_{5}$ does not show statistically significant differences.

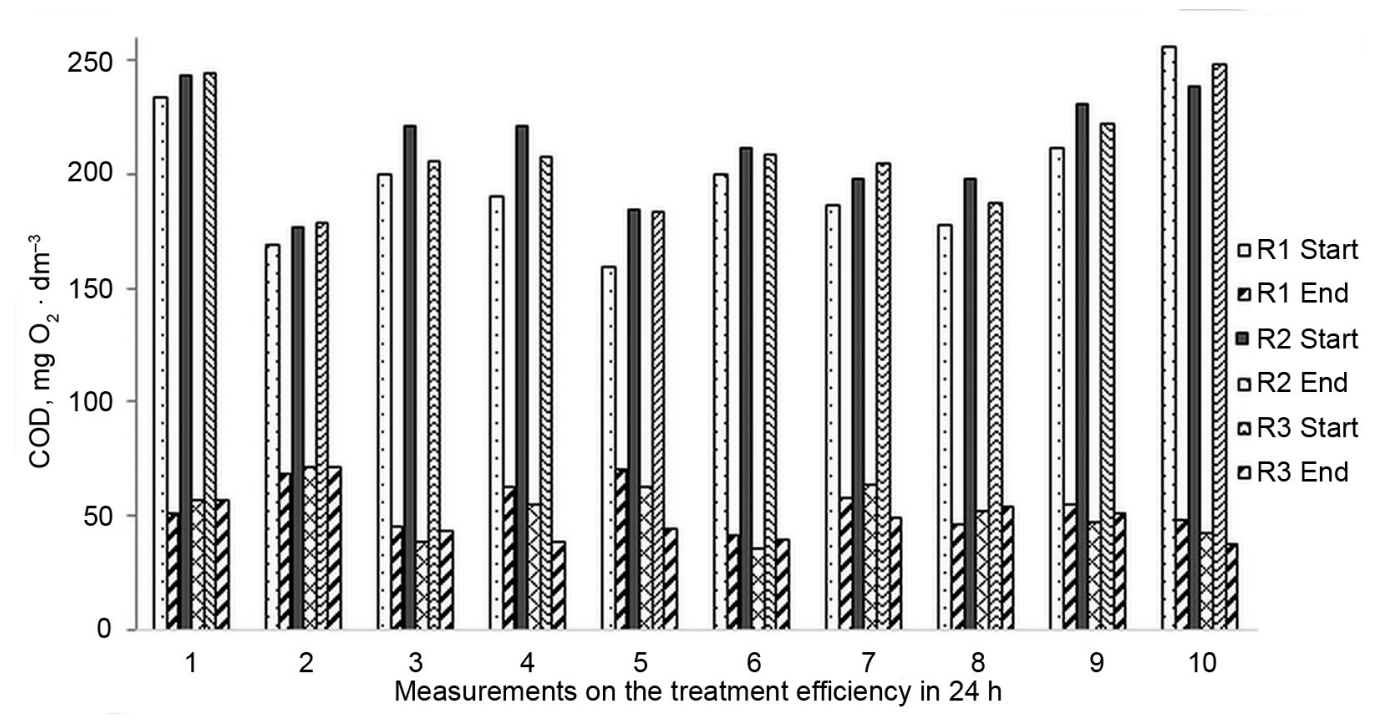

Fig. 5. COD reduction during wastewater treatment in experimental bioreactors for 24 hours 


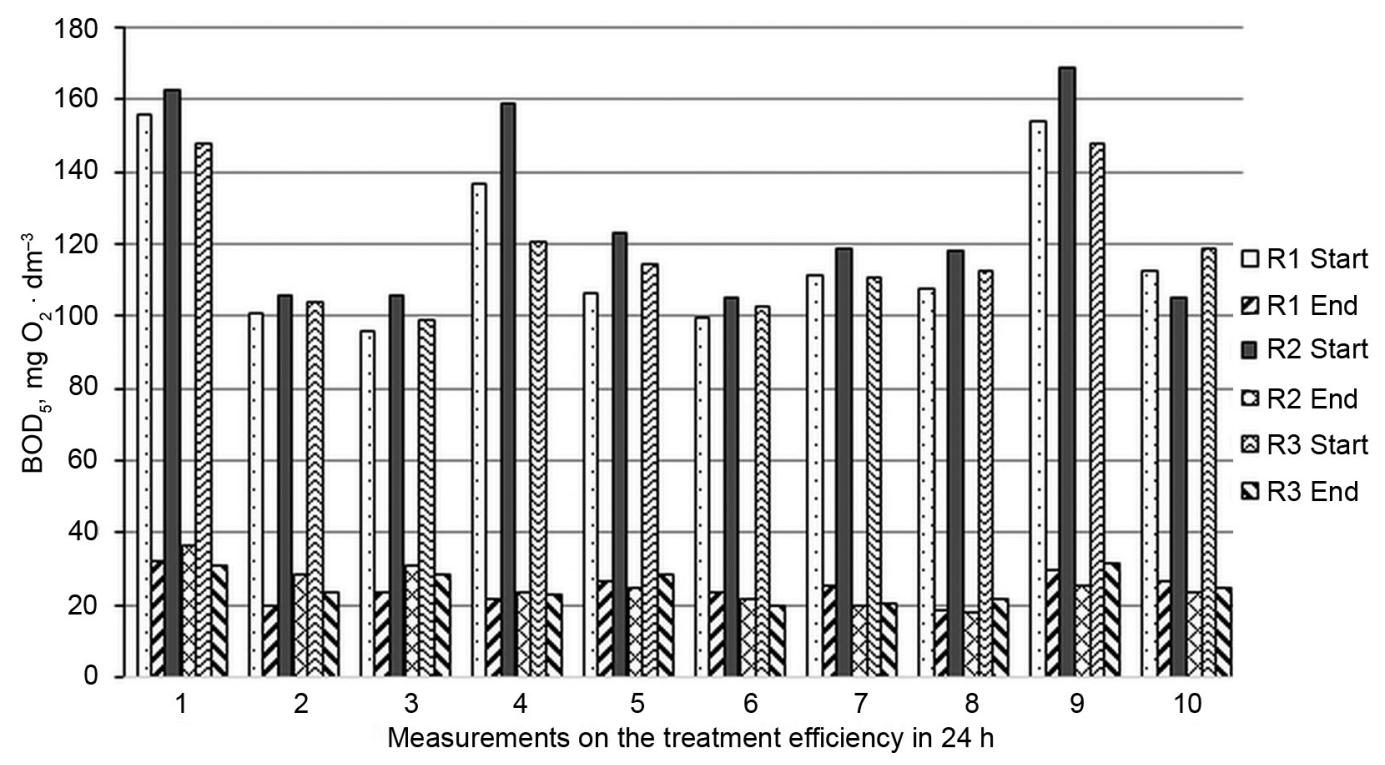

Fig. 6. $\mathrm{BOD}_{5}$ reduction during wastewater treatment in experimental bioreactors for 24 hours

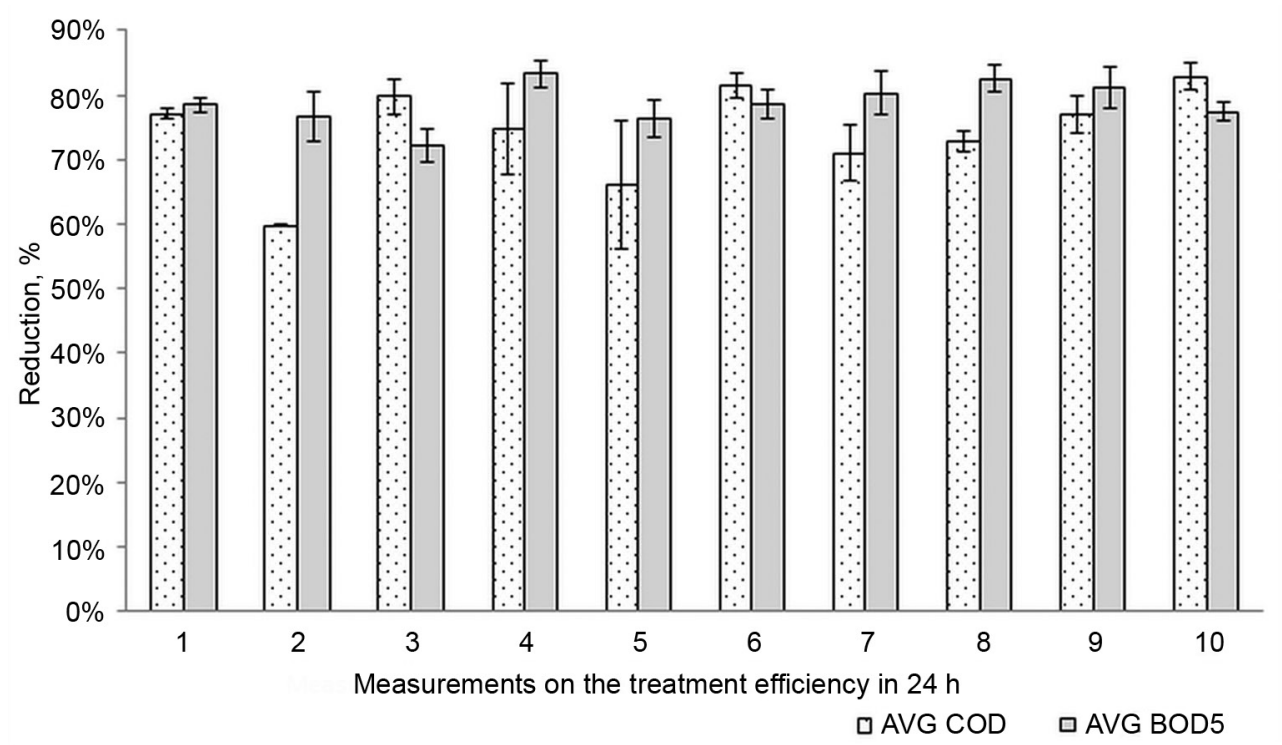

Fig. 7. Comparison of the average reduction of COD vs BOD after $24 \mathrm{~h}$ of the treatment process

Although the process has shown a reduction in nutrients during the treatment period (see: Fig 11), it is not efficient enough to prevent eutrophication. Both the reduction of ammonium and phosphate ions in this mode of operation of the installation requires further action (see: Fig. 8 and 9).
Online monitoring indicates that the quality parameters of treated wastewater are significantly improved in time from 11 to 13 hours (see: Fig. 11). 


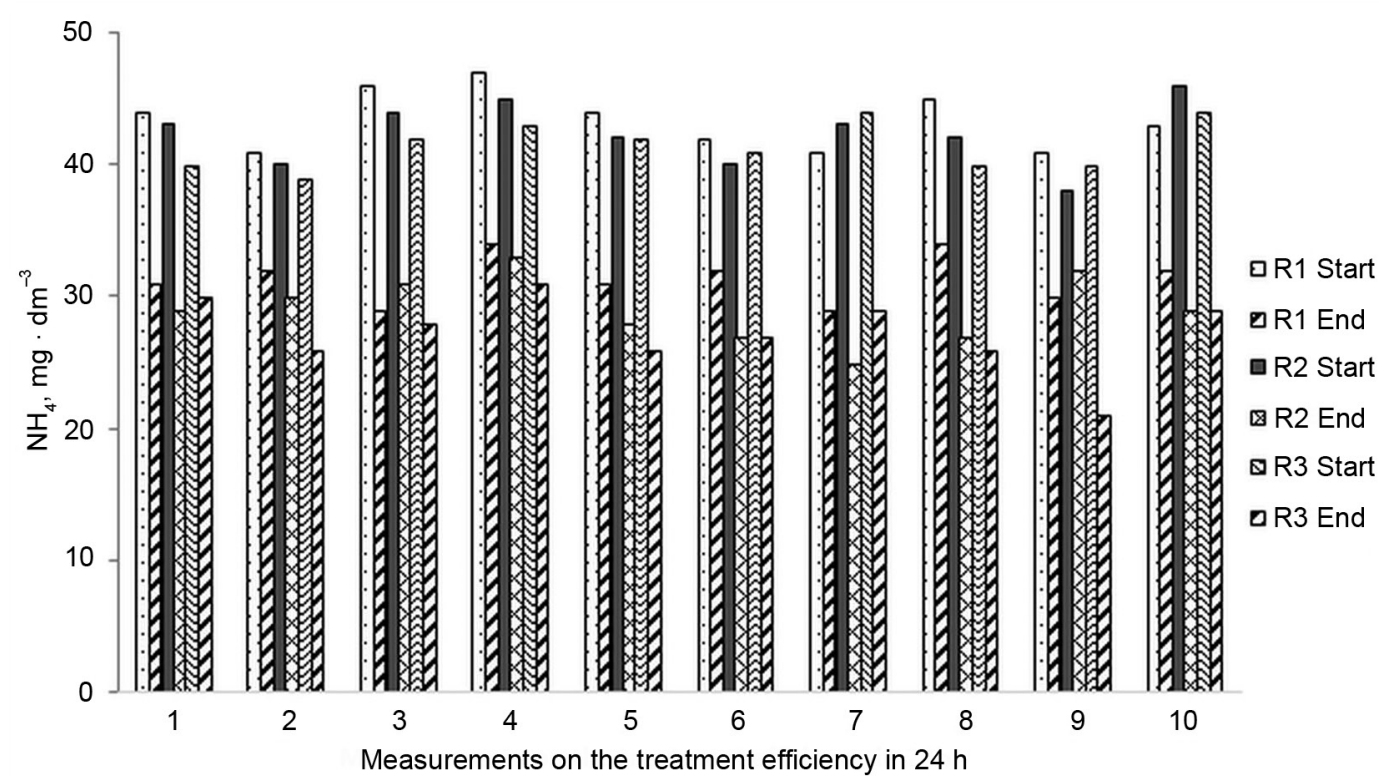

Fig. 8. $\mathrm{NH}_{4}^{+}$ions reduction during wastewater treatment in experimental bioreactors for 24 hours

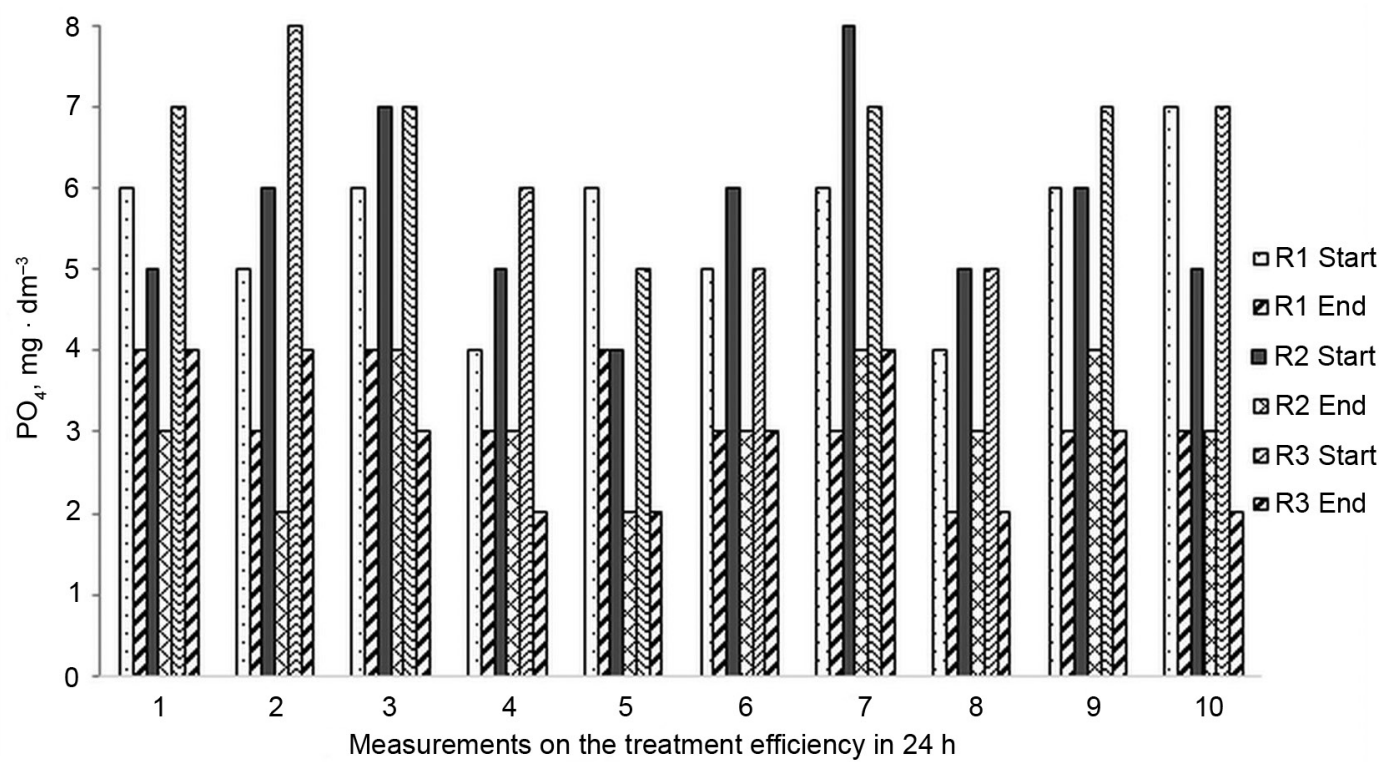

Fig. 9. $\mathrm{PO}_{4}^{3-}$ ions reduction during wastewater treatment in experimental bioreactors for 24 hours 


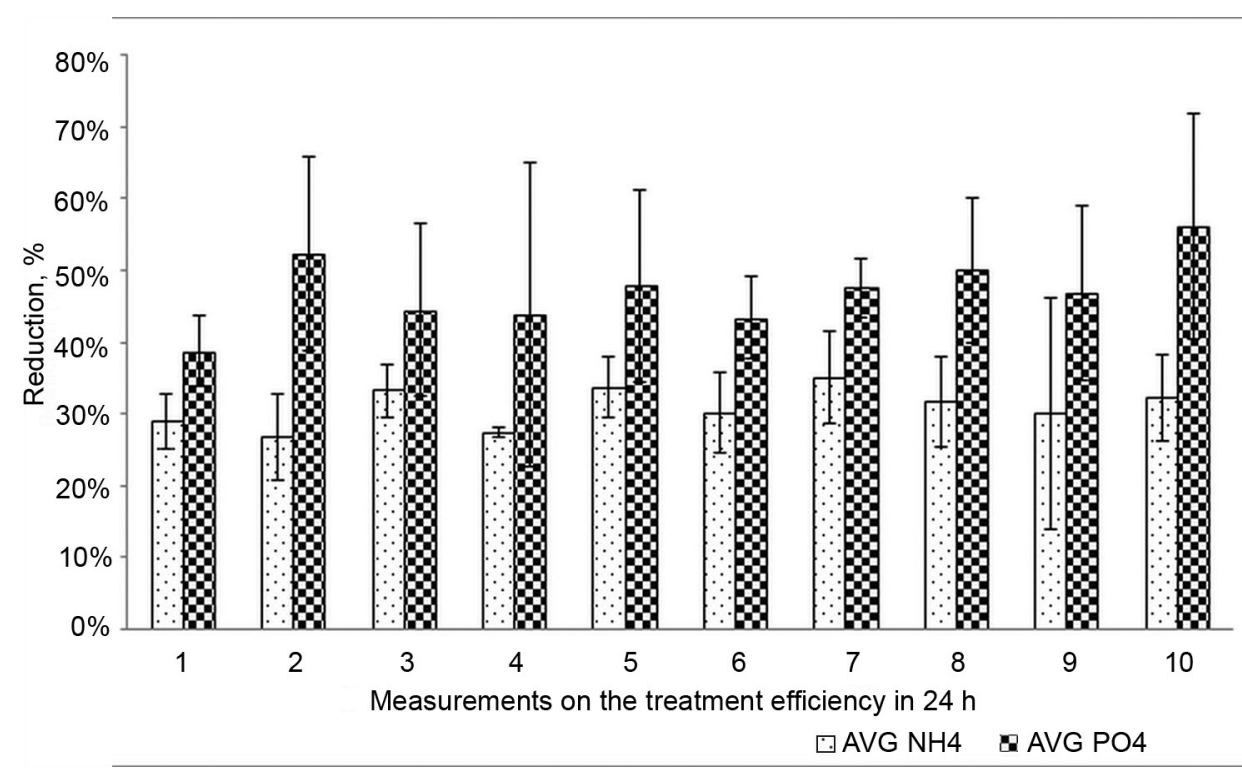

Fig. 10. Comparison of the average reduction of $\mathrm{NH}_{4}^{+} \mathrm{vs} \mathrm{PO}_{4}^{3-}$ after $24 \mathrm{~h}$ of the treatment process

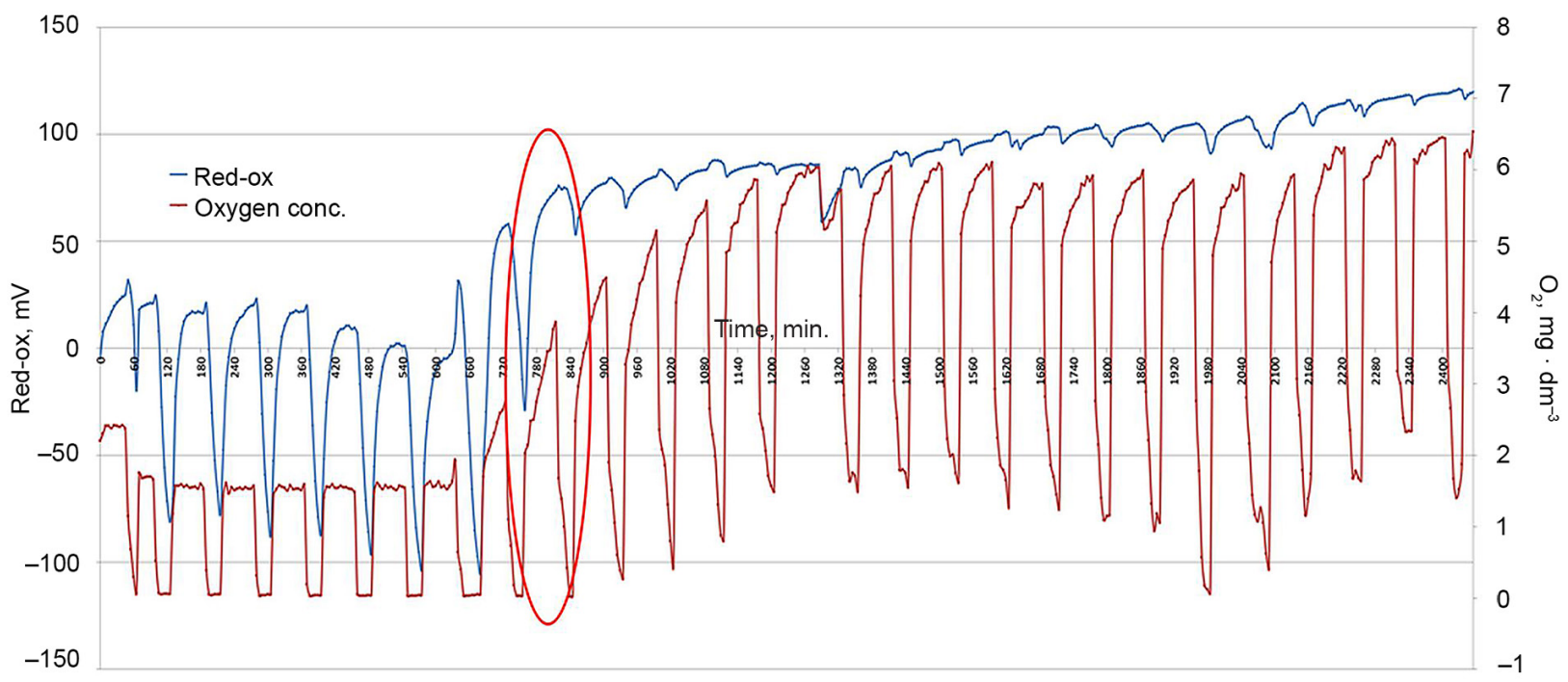

Fig. 11. Online monitoring of oxygen concentration and redox changes during the process of wastewater treatment

\section{DISCUSSION}

The author designed and constructed a prototype of the MBBR bioreactor for the purpose of the reclamation of small water reservoirs with a depth exceeding $2 \mathrm{~m}$.
Hydraulic testing allowed the initial recognition of the flow character and the determination of the retention time of pollutants in the biological bed (see: Table 1). The reactor operates in the full flooding mode and for these parameters, it obtained the best flow efficiency 
with the airflow of $Q_{p}=3-4 \mathrm{~m}^{3} \cdot \mathrm{h}^{-1}$ (see: Fig. 4). The $70 \%$ filling of the reactor chamber with biomass carriers is the maximum load that still allows the circulation of the bed at the above-mentioned air flow rates. (Barwal and Chaudhary, 2014). It is difficult to clearly state whether the calculated retention times will determine the required reduction of pollutants in the bed with continuous flow (see: Table 1) (Ødegaard, 2006; Tilley, 2011; Kershaw, 2015, Bugajski et al., 2016a; 2016b). In extreme cases of water reservoir pollution - additional support of the process may be required by dispensing microorganisms with a certain degree of affinity for the substrate (Sitarek et al., 2017). There is no universal scheme of the character of pollution of water reservoirs (Smith, 2013; Ji, 2017). In each case, it is necessary to carefully monitor water quality and perform risk analysis in order to take further actions related to risk management strategy (Hering et al., 2015). The application of MBBR in the treatment of polluted water reservoirs belongs to innovative solutions, which previously had been used only in some aquacultures with a high stocking density (Nowak et al., 2018). There are no literature data reporting on the results of pollution treatment with the application of analogous systems in open water reservoirs. The Japanese used the fluidized-bed biofilm reactor system for the mechanical reduction of suspension in eutrophicated water bodies (Tanaka et al. 2001). The results of biotechnological tests on a semi-technical scale indicate the possibility of effective elimination of organic pollutants (Fig. 5-7) (Nowak et al., 2018). The data on hydraulic tests, presented in this article, is very important for the configuration of final bioreactors on a technical scale in the conditions of water reservoirs with variable geometrical and qualitative parameters (see: Fig. 4).

Biotechnological testing showed that in quasi-continuous flows, after 24 hours, the degree of purification of organic pollution - one that had been heavy as for surface waters (see: Fig. 5, 6) - is satisfactory (Dochain and Vanrolleghem, 2001). The degree of COD and $\mathrm{BOD}_{5}$ reduction statistically shows no significant differences (see: Fig. 7). Monitoring of $\mathrm{O}_{2}$ concentration and redox can also be extremely helpful in estimating the rate of organic matter decomposition, and in determining the discharge time for the quasi-continuous mode. Presented results (see: Fig. 11) indicate intensive oxygen consumption during treatment process, but at higher concentration of organic pollutants the use of more efficient aeration systems is required. Based on the results of hydraulic and biotechnological testing, it was possible to determine the operating parameters of technological reactors and to determine the energy requirements of the system.

In further studies, the author is going to search for the best construction solutions for the building of a mobile reclamation platform that could carry out the purification process in a water reservoir. Platforms of this type will be a competition for chemical methods and pulverization reclaimers (Sobczyński et al., 2012). Although the literature describes many methods based on the use of artificial or natural wetlands (Hamilton and Collier, 2016), their applications are limited by many environmental or economic factors. The tested bioreactors also show possibilities of nutrient reduction (see: Fig. 8 and 9), which can additionally be supported by sorbents (Mazur at al., 2017; Wąsik at al., 2017 a). Unfortunately, the efficiency of nutrients removal without additional support is not sufficient (see: Fig. 10).

The author investigated the efficiency of organic pollutants treatment from the wastewater characterized by a small concentration of $\mathrm{COD}$ and $\mathrm{BOD}_{5}$, in order to simulate the conditions of heavily polluted water bodies (Usha et al. 2006). The studies were carried out in the temperature range $8-10^{\circ} \mathrm{C}$ characteristic for the conditions prevailing in the second half of October. Due to the significant tolerance of MMBR reactors to temperature changes, the treatment process on the biological bed was satisfactory (see: Fig. 7.) (Hoang et al. 2014).

High retention of the biomass of microorganisms that carry out the purification process in the biological beds of MBBR minimizes the formation of sludge and its sedimentation in purified water reservoirs (Comett-Ambriz et al., 2003; Chmielowski and Ślizowski, 2008). With the view to the significant demand for electricity for the operation of purification installations, the author already prepared a preliminary project of power supply from renewable energy sources on the water. 


\section{CONCLUSIONS}

1. The constructed reactors show a high potential for their application in the processes of the small water reservoirs' reclamation.

2. The obtained results constitute a valuable database for the construction of a technological model that can be easily adapted to the specific conditions of surface water pollution.

3. Hydraulic and biotechnological parameters obtained on the basis of experimental results will allow determining the time of water treatment process to obtain appropriate water quality effect.

4. Nevertheless, further testing is required in the season with low temperatures, and with the use of multi-chamber beds, which can further increase the efficiency of purification in field conditions.

\section{REFERENCES}

Andreottola, G., Foladori P., Ragazzi M., Tatano F. (2000a). Experimental comparison between MBBR and activated sludge system for the treatment of municipal wastewater. Water Science \& Technology, 41(4), 375-382.

Annor, F. O., Liebe, J., Van De Giesen, N. (2007). Near-Real-Time Monitoring of Small Reservoirs with Remote Sensing.

Ateia, M., Yoshimura, C., \& Nasr, M. (2016). In-situ Biological Water Treatment Technologies for Environmental Remediation: A Review. J Bioremed Biodeg, 7(348), 2.

Barwal, A., \& Chaudhary, R. (2014). To study the performance of biocarriers in moving bed biofilm reactor (MBBR) technology and kinetics of biofilm for retrofitting the existing aerobic treatment systems: a review. Reviews in Environ. Science and Bio/Tech, 13(3), 285-299.

Boix, D., Biggs, J., Céréghino, R., Hull, A. P., Kalettka, T., Oertli, B. (2012). Pond research and management in Europe:"Small is Beautiful". Hydrobiologia, 689(1), 1-9.

Borkar, R. P., Gulhane, M. L., \& Kotangale, A. J. (2013). Moving bed biofilm reactor-a new perspective in wastewater treatment. Environ. Sci. Toxicol. Food Technol., 6(6), 15-21.

Brönmark, C., \& Hansson, L. A. (2017). The biology of lakes and ponds. Oxford University Press.

Brucet, S., Poikane, S., Lyche-Solheim, A., Birk, S. (2013). Biological assessment of European lakes: ecological rationale and human impacts. Freshwater Biology, 58(6), 1106-1115.
Bugajski, P., Chmielowski, K., Kaczor, G., (2016a). Reliability of a collective wastewater treatment plant. Journal of Ecological Engineering, 17(4).

Bugajski, P., Chmielowski, K., \& Kaczor, G., (2016b). Optimizing the Percentage of Sewage from Septic Tanks for Stable Operation of a Wastewater Treatment Plant. Polish Journal of Environmental Studies, 25(4).

Chmielowski, K., Ślizowski, R., (2008). Defining the optimal range of a filter bed's d10 replacement diameter in vertical flow sand filters. Environment Protection Engineering, 34(3), 35-42.

Comett-Ambriz, I., Gonzalez-Martinez, S., Wilderer, P. (2003). Comparison of the performance of MBBR and SBR systems for the treatment of anaerobic reactor biowaste effluent. In 3 rd World Water Congress: Wastewater Treatment Plants 47(12), 155-161.

Cooke, G. D., Welch, E. B., Peterson, S., Nichols, S. A. (2016). Restoration and management of lakes and reservoirs. CRC.

Directive, W. F. (2000). EU Water framework directive. Directive 2000/60/EC.

Dochain, D., \& Vanrolleghem, P. A. (2001). Dynamical Modelling \& Estimation in Wastewater Treatment Processes. IWA.

Dziubiński, M. \& Prymer, J. (2009). Mechanics of two-phase fluids. Polish: Scientific and Technical Publishing in Warsaw. Ecological Engineering, 18(5), 555-574.

Hamilton, D. P., Collier, K. J., \& Howard-Williams, C. (2016). Lake restoration in New Zealand. Ecological Management \& Restoration, 17(3), 191-199.

Hering, D., Carvalho, L., Argillier, C., Beklioglu, M., Borja, A., Cardoso, A. C.,Hellsten, S. (2015). Managing aquatic ecosystems and water resources under multiple stress-An introduction to the MARS project. Science of the total environment, 503, 10-21.

Hoang, V., Delatolla, R., Abujamel, T., Mottawea, W., Gadbois, A., Laflamme, E., Stintzi, A. (2014). Nitrifying moving bed biofilm reactor (MBBR) biofilm and biomass response to long term exposure to $1 \mathrm{C}$. water research, 49, 215-224.

Hosseiny, S. H., \& Borghei, S. M., 2002. Modelling of organic removal in a moving bed biofilm reactor (MBBR). Scientia Iranica, 9(1), 53-58.

Husa, V., Kutti, T., Ervik, A., Sjøtun, K., Hansen, P. K., Aure, J. (2014). Regional impact from fin-fish farming in an intensive production area (Hardangerfjord, Norway). Marine Biology Research, 10(3), 241-252.

Ji, Z. G. (2017). Hydrodynamics and water quality: modeling rivers, lakes, and estuaries. John Wiley \& Sons. 
Jurik, L., Húska, D., Halászová, K., \& Bandlerová, A. (2015). Small Water Reservoirs-Sources of Water or Problems?. Journal of Ecological Engineering, 16(4).

Kershaw, G. B. (2015). Sewage purification and disposal. Cambridge University Press.

Larocque-Tobler, I. (2017). Using paleolimnology for lake restoration and management. Using Paleolimnology for Management and Restoration of Lakes, 5.

Liebe, J., Van De Giesen, N., \& Andreini, M. (2005). Estimation of small reservoir storage capacities in a semi-arid environment: study in the Upper East Region of Ghana. Physics and Chemistry of the Earth, A/B/C, 30(6), 448-454.

Mazur, R., Bedla, D., Chmielowski, K., Nowak, A., Mazurkiewicz, J. (2016). Wpływ warunków tlenowych na skuteczność oczyszczania ścieków bytowych w technologii zatapialnych filtrów włókninowych. Przemys Chem., 95(8), 1513-1517

Mioduszewski, W. (2014). Small (natural) water retention in rural areas. Journal of Water and Land Develop., 20(1), $19-29$.

Mioduszewski, W. (2012). Small water reservoirs-their function and construction/Małe zbiorniki wodne-ich funkcje i konstrukcje. Journal of Water and Land Development, 17(1), 45-52.

Mitsch W.J., Gosselink J.G. (2000). The value of wetlands: importance of scale and landscape

Nascimento, V. F., Ribeiro Neto, A. (2017). Characterization of reservoirs for water supply in Northeast Brazil using high resolution remote sensing. RBRH, 22.

Natarajan, P., Velraj, R., \& Seeniraj, R. V. (2008). Application of drift-flux model in liquid-solid circulating fluidized bed. Chemical Engineering Communications, 195(9) 1144-1158.

Nowak, A., Mazur, R., Panek, E., Chmist, J. (2018). Model Studies on the Effectiveness of MBBR Reactors for the Restoration of Small Water Reservoirs. In E3S Web of Conferences. EDP Sciences. 30. 02004

Ødegaard, H. (2006). Innovations in wastewater treatment: moving bed biofilm process. Water Science and Technology, 53(9), 17-33.

Oertli, B., Céréghino, R., Hull, A., Miracle, R. (2009). Pond conservation: from science to practice. Hydrob., 634(1), $1-9$.
Payen, J., Faurès, J., Vallée, D. (2012). Small reservoirs and water storage for smallholder farming. Agriculture Water Management Business Proposal Document.

Pokorný J., Hauser V. (2002). The restoration of fish ponds in agricultural landscapes. 18(5), 555-574.

Schwartz, S. S., \& Jenkins, D. G. (2000). Temporary aquatic habitats: constraints and opportunities. Aquatic Ecology, 34(1), 3-8.

Sitarek, M., Napiórkowska-Krzebietke, A., Mazur, R., Czarnecki, B., Pyka, J. P., Stawecki, K., Kapusta, A. (2017). Application of Effective Microorganisms technology as a lake restoration tool-a case study of Muchawka Reservoir. Journal of Elementology, 22(2), 529-543.

Smith, K. (2013). Environmental hazards: assessing risk and reducing disaster. Routledge.

Sobczyński, T., Joniak, T., Pronin, E. (2012). Assessment of the Multi-Directional Experiment to Restore Lake Góreckie (Western Poland) with Particular Focus on Oxygen and Light Conditions: First Results. Polish Journal of Environmental Studies, 21(4).

Tanaka, T., Tsuzuki, K., Nishijima, N., \& Takagi, T. (2001). Algae-removal performance of a fluidized-bed biofilm reactor system for lake water treatment. Water science and technology, 43(1), 277-283.

Tilley, D. F. (2011). Aerobic wastewater treatment processes. Iwa Publishing.

Uberman, R., Ostręga, A. (2012). Reclamation and revitalisation of lands after mining activities: Polish achievements and problems. AGH Journal of Mining and Geoeng., 36(2), 285-297.

Usha, R., Ramalingam, K., Rajan, U. B. (2006). Freshwater Lakes - A potential source for aquaculture activities A model study on Perumal Iake, Cuddalore, Tamil Nadu. Journal of environmental biology, 27(4), 713-722.

Wasik, E., Bugajski, P., Chmielowski, K., Nowak, A., \& Mazur, R., (2017a). Crystallization of struvite and hydroxyapatite during removal of biogenic compounds on the filter bed. Przemysl Chemiczny, 96(8), 17391743.

Wąsik, E., Chmielowski, K., \& Operacz, A. (2017b). PCA jako narzędzie eksploracji danych charakteryzujących pracę komór nitryfikacji oczyszczalni ścieków w Trepczy. Acta Sci. Pol. Formatio Circumiectus, 16(1), 2017. 


\section{KONCEPCJA REDEGRADACJI ZANIECZYSZCZONYCH MAŁYCH ZBIORNIKÓW WODNYCH PRZY ZASTOSOWANIU TECHNOLOGII MBBR}

\section{ABSTRACT}

\section{Cel pracy}

Zadaptowanie technologii MBBR do oczyszczania wód powierzhniowych. Zbadanie efektywności oczyszczania zanieczyszczeń organicznych w wodach o wysoce zanieczyszczonych ściekami komunalnymi (lub łatwo biodegradowalnymi ). Sprawdzenie skuteczności usuwania biogenów w trakcie procesu oczyszczania tego typu zanieczyszczeń.

\section{Materiał i metody}

Badania prowadzone w warunkach laboratoryjnych w skali ćwierć technicznej. Oczyszczano rozcieńczone ścieki bytowo-komunalne w celu określenia efektywności oczyszczania dla każdego stanowiska badawczego. Doświadczenia prowadzono w 4 stanowiskach badawczych (V ścieków $=1000$ L), każde zaopatrzone w bioreaktor MBBR z wpracowanym złożem biologicznym. Badano parametry fizykochemiczne $\mathrm{pH}$, red-ox, stężenie tlenu, oraz wykonano analizy laboratoryjne dla wskazania zmian w ChZT, BZT5, oraz wybranych formach biogenów $\mathrm{NH}_{4} \mathrm{i}_{\mathrm{PO}_{4}}$. Na podstawie uzyskanych wyników wykazano efektywność oczyszczania oraz zamodelowano parametry hydrauliczne instalacji.

\section{Wyniki i wnioski}

Wyniki prac eksperymentalnych wskazują na znaczącą efektywność procesu oczyszczania oraz usuwania biogenów w instalacjach MBBR. Po zaprojektowaniu odpowiedniej platformy pływającej można będzie tego typu instalacji wprowadzić do zdegradowanych zbiorników wodnych w celu ich oczyszczania.

Słowa kluczowe: oczyszczanie ścieków, zanieczyszczenia wód, MBBR, redegradacja zbiorników wodnych 